\title{
Against African Communalism
}

\section{Olúfémi Táíwò}

Journal of French and Francophone Philosophy - Revue de la philosophie française et de langue française, Vol XXIV, No 1 (2016) 81-100.

\author{
Vol XXIV, No 1 (2016) \\ ISSN 1936-6280 (print) \\ ISSN 2155-1162 (online) \\ DOI 10.5195/jffp. 2016.759 \\ www.jffp.org
}

\section{(c)) BY-NO-ND}

This work is licensed under a Creative Commons Attribution-Noncommercial-No Derivative Works 3.0 United States License.

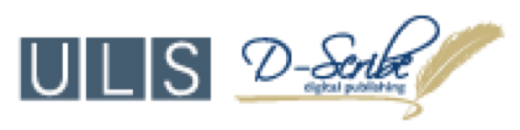

This journal is operated by the University Library System of the University of Pittsburgh as part of its D-Scribe Digital Publishing Program, and is co-sponsored by the University of Pittsburgh Press 


\title{
Against African Communalism
}

\author{
Olúfémi Táíwò
}

Cornell University

I

Communalism and its cognates continue to exercise a vise grip on the African intellectual imaginary. Whether the discussion is in ethics or social philosophy, in metaphysics or even, on occasion, epistemology, the play of communalism, a concept expounded in the next section, is so strong that it is difficult to escape its ubiquity. In spite of this, there is little serious analysis of the concept and its implications in the contemporary context. Yet, at no other time than now can a long-suffering continent use some robust debates on its multiple inheritances regarding how to organize life and thought in order to deliver a better future for its population. Given the continual resort to communalism as, among others, the standard of ethical behavior, the blueprint for restoring Africans to wholeness and organizing our social life, as well as a template for political reorganization across the continent, one cannot overemphasize the importance of contributing some illumination to the discourse surrounding the idea. This essay seeks to offer a little illumination in this respect. Additionally, it offers a criticism of what allproponents and antagonists alike-take to be a defensible version of communalism: moderate communalism. I shall be arguing that communalism, generally, has a problem with the individual. And the African variant of it, mostly subscribed to by the African scholars discussed below and defended by them as something either peculiar to or special in Africa, has an even harder time accommodating the individual. Yet, as history shows, until the modern age in which individualism is the principle of social ordering and mode of social living, a situation that privileges the individual, above all, various forms of communalism never really accorded the individual the recognition and forbearances that we now commonly associate with the idea. The strongest variants of moderate communalism discussed here have a difficult time taking the individual seriously. I am not aware of anyone else ever having made such a case. ${ }^{1}$ These arguments are offered to show that (1) Africa and Africans need to take individualism seriously and (2) such have been the historical transformation that our 
diverse societies have undergone in the course of the last half a millennium that the types of communalism that are on offer do not appear to take this fact of radical change with the necessary urgency.

II

Before making the case against African communalism, it is meet to clear some conceptual ground. We can distinguish at least three theses of communalism. ${ }^{2}$ The first, ontological communalism, is a thesis about how humans are in the world and what they are. On this reading, being-incommunion is the natural way of being human. One cannot think of human beings in the world without thinking of them in communion\community with one another. A human being who is outside of this communion \community will, ex definitione, be a non-human. Certainly, it is easy to see how one might build some prescriptive theses on this foundation but there is no necessary connection between this description and a value preference. Many who canvass communalism in the African context subscribe to this thesis. ${ }^{3}$ In fact, many of them are not beyond suggesting that this being-in-community is the quintessential way of being African, a position scrutinized later in this discussion. ${ }^{4}$

The second is the methodological thesis: no matter how humans are in the world, we are best placed to make sense of their being-in-the-world and their activities attached thereto if we view them through the prism of community. This is an explanatory model. On this construal, when we wish to explain social phenomena, including human behavior, we should frame our explanation in terms of the activities of humans-in-groups and the behavior of groups. Those who are familiar with debates in the philosophy of the social sciences can easily see the convergence here between what I have called methodological communalism and various types of what is called methodological holism. The contrast is drawn with methodological individualism the many variants of which insist on one core claim: those explanations of social phenomena are best which are framed in terms of, or ultimately refer to, the understandings, behavior, or activities of named or nameable individuals. The best and most sophisticated account of what can be considered methodological communalism in the current context is that of Akinsola Akiwowo. But he advances it as social theory and as a distinctive African-derived explanatory model for social phenomena. Unfortunately, African intellectuals, especially those who embrace communalism, do not pay any heed to his work. Akiwowo has formulated a sociological theory drawn from Yorùbá culture with which to unravel the complexities and causes as well as the course of social change in the African context; his theory represents an excellent example of methodological communalism. ${ }^{5}$

The third, axiological, thesis holds that communalism provides a yardstick with which to measure the desirability or worth of being-in-the-

Journal of French and Francophone Philosophy | Revue de la philosophie française et de langue française

Vol XXIV, No 1 (2016) | http://www.jffp.org | DOI 10.5195/jffp.2016.759 
world. Attention here turns on value theory. Many of the strictures that communalists place on contemporary urbanization-inflected social living and the atomization that characterizes it are on account of the individualism that is inspired, supposedly, by Africans copying Western values. Individualist behavior is excoriated and those who embrace it, however it is conceived, stand condemned for abandoning a superior mode of social living: communalism. In this context, scholars evaluate-as opposed to explain, under the methodological version-social phenomena, institutions, and practices, including human behavior, in terms of how well or ill they reflect, embody, or advance communalism and its tenets. When they reflect well, they are good; when not, they are bad. When we apply this to behavior and we understand it in terms of answering the question of what we ought to do in any given situation, we have the following: that ought to be done which advances the well-being of the community, makes the individual a better member of the community, and so on. This is axiological communalism.

If what is to be judged is behavior or conduct, we call it communalist ethics. If, however, what is to be judged is the suitability of modes of governance or principles of social living or ordering, resolving issues of who ought to rule when not all can rule and what end legitimate rule should tend to, we call it communalist social and political philosophy or socio-political communalism. This will be relevant, let us say, in the design of social institutions or what political institutions are most likely to ensure a better life for humans. We can easily see how one who thinks that the system is too individualist would prefer communalism. In the political arena, one can trace much of the preference of African philosophers for one-party regimes or consensus politics to this preference for communalist arrangements. They may be taken as instances of socio-political communalism. ${ }^{6}$ We have decided to group ethics and social and political philosophy together because both relate to assigning, determining, and weighing values of a normative character. ${ }^{7}$

There might even be a fourth, the epistemological thesis, which might in some way coincide with Polycarp Ikuenobe's defense of what he calls "epistemic authoritarianism" founded on deferring to superior wisdom modulated by age and collective knowledge. ${ }^{8}$

III

The literature on communalism scarcely, if ever, evinces any awareness of the distinctions just made. The result is a lot of confusion as to what exactly is at issue in these disquisitions. Identifying and distinguishing these different theses of communalism can illuminate a discussion that is often notorious for its murkiness, as is shown below.

Journal of French and Francophone Philosophy | Revue de la philosophie française et de langue française Vol XXIV, No 1 (2016) | http://www.jffp.org | DOI 10.5195/jffp.2016.759 
Separating these theses is likely to enhance the sophistication of the discourse of communalism. For example, the ontological thesis can be defended on several grounds, including conceptual and empirical ones. Because it is not recognized as such, many who canvass it seem to be offering empirical grounds for it. Yet, it is clear that historically it is less true of many African societies, especially those that evolved great civilizations. ${ }^{9}$ One could also advance communalist ethics but not defend it on empirical but ahistorical grounds as is usually done in the literature. What is more, by so championing communalism, we can broaden the scope of its desirability beyond Africa and, as all philosophical models are wont to do, enfold the rest of humanity as a route to a better way of being human-in-society.

Polycarp Ikuenobe has, arguably, done the most thorough job in recent times of clarifying the idea of African communalism. In his Philosophical Perspectives on Communalism and Morality in African Traditions, ${ }^{10}$ he identifies, beyond the standard radical versus moderate standpoints, multiple senses of communalism. But even he does not, in the final analysis, escape the lumping together of different theses. First, he seems to defend some variant of "the African communal tradition." It is difficult to put this charge more directly. Throughout the book, he talks about African culture, tradition, traditional society, traditional culture, and so on, sometime in the singular and, at the other times, in the plural. He makes clear that if he talks at all about anything that resembles a generalization about Africa, it is not a descriptive generalization of what communalism is in all African cultures, but a conceptual normative generalization. As a conceptual normative generalization, I am taking and defending a systematic philosophical position regarding how the idea of communalism ought to be understood in African cultures. In my analysis, I indicate some of the important features of communalism that can be extrapolated from many African traditional ways of life. The idea of communalism, in its very broad and pervasive sense, is one common or dominant theme or feature in African cultures that emerges from the African "way of life."11

Is it possible that, as a construct of Ikuenobe's imagination, communalism does not describe the empirical state of African societies now or in the past? Might one derive a different, maybe even opposed, "conceptual normative generalization" from the same empirical data plumbed by Ikuenobe? Are the commonalities cited as the base for his generalization what he has cashed them out to be? Despite all the caveats, Ikuenobe's account still strikes me as just another way of affirming a problematic stance: that most of what are styled "traditional African societies" were communalist. As I have argued elsewhere, ${ }^{12}$ the idea of "traditional African society $\backslash$ ies" is problematic, to say the least; most likely, as a theoretical concept, it is vacuous. For the case can be made that most of the commonalities that are often trumpeted as typifying African cultures are not peculiarly, predominantly, not to say solely, African. The contrast

Journal of French and Francophone Philosophy | Revue de la philosophie française et de langue française

Vol XXIV, No 1 (2016) | http://www.jffp.org | DOI 10.5195/jffp.2016.759 
between the Western and the African is hardly ever illuminating; often they obscure and this should not come as a surprise: it frequently is motivated by the need to affirm African difference.

Africans need to abandon the legacy of colonial-inflected anthropology that lumps together several social types that serious study should easily make clear do not belong together. How communalistic could the medieval Mali Empire have been? Once Islam became the principle of legitimacy when it came to governance, how much communalism and how "traditional" could such polities be? The Òyọ́ Empire was a multinational polity that had within its borders different national and ethnic groups. On what basis could one affirm of $17^{\text {th }}$ century ọ̀y with its hierarchiesincluding an aristocracy and monarchy that lived off the surplus labor of others-and a complex division of labor that it was a so-called "traditional society"? Meanwhile, in the various communities that made up Igbo people, their scholars and ideologists love to trumpet their traditional preference for republicanism and their storied individualism. Yet, scholars love to talk of "traditional Igbo society" and affirm communalism of it in the singular.

Next, Ikuenobe declares that he is "doing a conceptual normative analysis of how communalism ought to be understood based on theoretical generalization and abstraction." ${ }^{13}$ This was his attempt to beat back the charge that all such talk was founded on insufficient evidence. Yet, at another place, he declares that his "defense of communalism involves a critique of the dominant liberal individualistic theoretical and political view in the West." ${ }^{14}$ Outside of this overarching need to treat the West as a monolith in order thereby to affirm Africa in its radical difference, this cannot be a very plausible idea unless it can be shown that communalism, even of the variety that Ikuenobe defends, is not part of the philosophical history of the so-called West. Certainly, given that many of us African scholars engaged in this debate are native speakers of the so-called Western philosophical idiom, we can assert that we know that not too dissimilar versions of communalism are significant parts of "the Western tradition".

In a different context, Ikuenobe seeks "to provide a view of communalism that is sensitive to the African lived experiences and ways of life. In this sense, communalism is of interest to Africa and Africans, in that it provides a plausible conceptual and rational basis for explaining the reality and experiences in African cultures and perhaps, their own identity in the midst of Western culture,"15 which makes it a version of the methodological thesis. The only problem is that Ikuenobe does not tell us where and how this explanatory model is to be deployed. Is it to be deployed by all Africans, per se, or African immigrants in the West? In Asia? Or in North America? Or is it also to be used by Africans resident in African countries? Does it matter that such Africans are now predominantly Christians or Muslims? And what results are we supposed to gain from its 
deployment? Is this model available for the rest of humanity, a requirement it must satisfy to be a good theory?

Finally, communalism, for him, "involves certain principles regarding how a community is organized, the nature of the relationship that must exist between these communal principles and individuals, and the responsibilities that individuals must meet in order to achieve personhood." 16 Here we have a mix of ethical and ontological communalism, the version most often advanced in the literature. It is what Wiredu and Kwame Gyekye, among others, in their different ways, defend.

The many senses of communalism in Ikuenobe's discussion show how in a single author we can see all three theses represented without any hint on the author's part that anything might be amiss. He does distinguish between the political theory of communalism and the other uses to which he put the idea in Philosophical Perspectives on Communalism and Morality in African Traditions. Isolating the different theses, as has been done here, will show that one can subscribe to one or a combination of the theses without subscribing to all of them. Nor is it the case that they all cohere together in a tensionless unity and I submit that this awareness is lacking in much of the literature on African communalism. Furthermore, it will help if defenders like Ikuenobe and Wiredu would essay to show the material or conceptual differences between African communalism and other variants that are to be found in other cultures and traditions or, minimally, what is particular to the African variety. ${ }^{17}$

Ultimately, Ikuenobe offers a series of moves designed to show that communalism is a breed of African philosophy, instantiated in ethics, education, and epistemology. My interest has not been in engaging the claims. My interest-and here I may be vulnerable to some of Ikuenobe's strictures on universalism-is in examining whether or not communalism offers us a more insightful way of making sense of being human in the world. The Africanness of communalism cannot suffice to ground its universal desirability; it must have more to recommend it. For if it were to aspire to universalizability, then its Africanness cannot serve as a marker that many of its defenders claim it is, especially when they distinguish it from the individualism they identify with the West. I do not suggest that communalism may not be African because it is universal; it can be both. But to insist upon it as something especially African requires a more stout and sustainable defense.

IV

The version of examined in this section was originally deployed in the anti-colonial struggle and it was designed to provide a template for remaking African societies in light of the depredations of colonialism.

Journal of French and Francophone Philosophy | Revue de la philosophie française et de langue française

Vol XXIV, No 1 (2016) | http://www.jffp.org | DOI 10.5195/jffp.2016.759 
Additionally, it was a weapon in Africa's arsenal of ideas against global white supremacy that had denied that Africa had any past worthy of note outside of its incorporation into European-directed global politics. Thinkers in this mode were concerned to answer Europe's denial with African affirmations. It is time to turn to Leopold Sédar Senghor, an ardent proponent of socialism. He wanted to show that socialism had antecedents in the African past and would therefore be an easier fit than the individualism-inflected, capitalism-dominated system imported from Europe via colonialism. But Senghor was a much more sophisticated thinker, possessed of a more nuanced understanding of intellectual history, especially of Euro-American philosophy.

In his discussion of "the African road to socialism,"18 Senghor was concerned to distinguish Africans from Europeans, not Westerners, as a basis for extracting what he wished to celebrate as the African genius and how it might be deployed in the reconstruction of the African continent in the aftermath of slavery, the slave trade, Islamization, Christianization, conquest, and colonialism. Of course, Senghor's discussion unfolded in the context of the denial of African achievements by white supremacists in the period before and during colonialism. Senghor's motivations were more of the axiological variety. ${ }^{19}$ He wanted to offer a model of how African societies might be rebuilt in the aftermath of the events just mentioned as well as the transformations that had occurred as a consequence of Africa's historical engagements with Islam, Christianity and European culture in general.

But, unlike many who affirm African achievements, Senghor did not subscribe to the metaphysics of difference that has informed the view of Africa and Africans manufactured by colonial ideologists. On the contrary, he was careful to insist that there was nothing peculiarly African about communalism and that the task of reconstruction must be an "attempt to define an ideal society that will integrate the contributions of European socialism with our traditional values. This integration is necessary since our society today, in 1960, is neither the Negro-Berber society of the Middle Ages nor that of contemporary Europe. Our present society is in fact an original one, economically and culturally mixed, with African and European contributions." ${ }^{20}$ Although it will take us too far afield to expound the issues involved, we must not fail to note the historicity that marks Senghor's postulations: note, for instance, the specific references to time and periods"today, in 1960", "Middle Ages", "contemporary Europe"-represent more promising, for theory, temporal horizons than the popular simplistic "precolonial, colonial, and postcolonial" periodization that dominates much of the discourse of communalism at the present time.

In addition to the axiological bent of his discussion, Senghor deploys the ontological thesis but that is because he wants to show that what he proposes, his ultimate philosophical construct, was not completely alien to the African context; it did have an African pedigree. After all, he says that

Journal of French and Francophone Philosophy | Revue de la philosophie française et de langue française Vol XXIV, No 1 (2016) | http://www.jffp.org | DOI 10.5195/jffp.2016.759 
the "present society is in fact an original one, economically and culturally mixed, with African and European contributions". Not for him the willful erasure of the hybridity of African societies as at the time that he was writing or the heterogeneity of the elements that made up the Negro-African society he was describing. Hence, his description of what he calls "NegroAfrican society" as mixed; it is by no means "purely African".

It is also not insignificant that he does not talk about African nature or personality, focusing instead on types of society-constructs, if there be any-marked indelibly by their historicity and the kinds of persons $\backslash$ beings that inhabit them. Rather, his ideal society is better in comparison with others precisely because it will combine the best of all the influences that are in play in the African situation, both those that are autochthonous and the rest that are exogenously derived. The combination will not be African but, shall we say, Senghorian. And if it is African at all, it would be so only nominally or, at best, a representation of what African genius-human genius resident in Africa-has wrought. Needless to say, what would recommend it to others will not be its African pedigree or the fact that it works for Africans; what will make people want to embrace it is that it promises to deliver the best possible society for humans.

West African countries and European ones are not different on account of the different kinds of humans that live in them. Their difference is historical and therefore contingent. The primary difference between West African countries and European ones is that the former are "community countries where the group holds priority over the individual; they are, especially religious countries, unselfish countries, where money is not King." ${ }^{21}$ Here, again, Senghor speaks in terms not of peoples but of countries and societies. The preference for identifying groups by other than primordial characteristics or loyalties means that how the groups organize their lives and procure their sustenance is more significant than who they are as peoples. Countries and societies are more likely to be hetero- than homogeneous in their demographic make-up.

We have, then, a description that contrasts what Senghor calls "community countries" with those that are not. Community countries have their peculiar features chief among which is the fact that, in them, the group is prior to the individual. Here is the contrast fully drawn:

To return to the distinction between Negro-African and collectivist European society, I would say that the latter is an assembly of individuals. The collectivist society inevitably places the emphasis on the individual, on his original activity and his needs. In this respect, the debate between "to each according to his labor" and "to each according to his needs" is significant. Negro-African society puts more stress on the group than on the individual, more on solidarity than on the activity and needs of the individual, more on

Journal of French and Francophone Philosophy | Revue de la philosophie française et de langue française Vol XXIV, No 1 (2016) | http://www.jffp.org | DOI 10.5195/jffp.2016.759 
the communion of persons than on their autonomy. Ours is a community society. This does not mean that it ignores the individual, or that collectivist society ignores solidarity, but the latter bases this solidarity on the activities of individuals, whereas the community society bases it on the general activity of the group. ${ }^{22}$

The difference is one of degree, not of kind. An assembly of individuals and a community society are not mutually exclusive; each contains elements of the other as subordinate moments of its totality. ${ }^{23}$ It is just that different principles of justification are deployed in each group. Prospering the individual and deferring to her dominates in one but not in the other; and vice versa. Senghor's is one of the more sophisticated versions of communalism available in the literature. Solidarity in one is marked by individual constructions; in the other, it is denominated by how integral such instances are to the "general activity of the group."

We may understand an "assembly society" as one in which being together, by itself, is not salient: each is independent of and primarily unconnected to $\backslash$ with the other. Each does her thing, as it were, as she sees fit and the main motivation for acting is the advancement of self-interest and whatever solidarity may subsist will be contrived, not immanent. "Community society", on the other hand, is characterized by a communion in which each is a part and her being a part implies a primary absence of autonomy or of its salience. The solidarity of the "community society" is immanent to it and the group represents a causal force that can and does act upon individuals regardless of their preferences. Yes, there often is community among members of an "assembly society" but it is no more than an occasional convergence of interests undergirded by negotiation among its autonomous members. In a "community society" by contrast, community is prior and takes precedence over the individual. In the former case, the community must justify itself to the individual; in the latter, the individual must justify herself to the community. ${ }^{24}$

What sets one apart from the other is the specific configuration of individuals and groups. There are no ontological flights of fancy here. Needless to say, each characterization is best read as an attempt to capture social phenomena and explain how they emerge and $\backslash$ or operate and how best to make sense of them. What is at the fore here is that individuals and groups form a dialectical whole. It all depends on which moment of each whole is dominant at any given time and over the long haul. But by no means will it be correct to say, as Wiredu does, that the relationship between the individual and the group is symmetrical in either case. ${ }^{25}$ Each is tilted towards the group or the individual, as the case may be.

Senghor describes the relationship among individuals, their attitudes to their group; what the limits are of what each owes the other within the

Journal of French and Francophone Philosophy | Revue de la philosophie française et de langue française Vol XXIV, No 1 (2016) | http://www.jffp.org | DOI 10.5195/jffp.2016.759 
context of their social living; what is and what is not permissible to do to, with, and on the body and property of another; and the nature of the relationship between the group and the individuals that make it up. There is no suggestion here that one form of being is natural to one or the other group or that one people are more group-inflected and the other individualoriented. There are communities in Africa as there are in Europe; so are individuals.

We see this in Senghor's consideration of the relationship between the community and individuals and how community societies deal with the individual:

Let us guard against believing that the community society ignores the person, even if we believe it neglects the individual. The individual is, in Europe, the man who distinguishes himself from the others and claims his autonomy to affirm himself in his basic originality. The member of the community society also claims his autonomy to affirm himself as a being. But he feels, he thinks that he can develop his potential, his originality, only in and by society, in union with all other men-indeed, with all other beings in the universe: God, animal, tree, or pebble. ${ }^{26}$

The assertion of will confirms the being of the individual but he is shorn of the considerations that are due a person. Growing from being and developing towards personhood requires deference to the group and its preferences. Although the empirical claim that the individual "thinks, feels that he can develop" only in and by society strikes me as special pleading, it is plausible. We ignore for the moment the undischarged distinction between being and person. The assumption here is that a being is not a person, without more; the person, on the other hand, is not coeval with the individual. Persons are individuals who think, feel that they can develop only in and by society. A person in assembly society will be a nonperson in community society for the grounds of their respective personhoods differ. Personhood in assembly society is based on individuality and in community society, on community. This is why in the latter society the individual is neglected. ${ }^{27}$ If the inhabitants of the community society include individuals who differ with their fellows in matters of conceptions of the good life and how best to realize them, it is obvious that Senghor's schema has no provision for such beings. For one thing, in his schema, they appear to be non-persons, given their heterodox beliefs. If this is so, "neglecting the individual" is a lot graver phenomenon than Senghor's discussion might lead us to think. ${ }^{28}$

We let stand the undischarged distinction between person and individual. What follows? It definitely does not follow that the individual in "assembly society" does not think that he needs the company of others to develop; what he does not grant is that he needs the communion with others

Journal of French and Francophone Philosophy | Revue de la philosophie française et de langue française

Vol XXIV, No 1 (2016) | http://www.jffp.org | DOI 10.5195/jffp.2016.759 
to be, or that his needing others makes him inferior to and, therefore, always needing to defer to his fellows. It is curious that Senghor appropriates the idea of the "person" to the more amorphous metaphysical category of "being". By so doing, he makes it seem as if the "being" of "community society" is undifferentiated, unindividuated, and assumed without tension, much less conflict. She is just one in a multiplicity of beings, including, as he says, "all other beings in the universe". How this could be construed as a serious recognition of the individual in the scheme of things is puzzling. The person is only a person in being with others; as a "person" outside this organic totality, she is a mere being. The individual is being-without-others, a person several notches beneath a real person, on this conception. By defining-yes, this is done by definition-the person as the undifferentiated being-in-communion, Senghor hopes to persuade his readers that he has answered the challenge that the idea of the individual poses to his characterization. The challenge, however, cannot be elided that easily. ${ }^{29}$ Recognizing a person requires social engagement, boundaries, etc. Recognizing an individual is just that: a nominal identity. Hence, the comparison to other beings that are apprehended in their individuality and mutual indifference; they are inert.

$\mathrm{V}$

Let us examine this objection to Senghor more fully. Although Senghor did not identify communalism as African even though instances of it are to be found in the continent, his less careful successors have sought to affirm it as a marker of difference between Africa and the rest of the world, especially Europe. We can affirm communalism of much of the human race and various societies at different times in the past whether in Europe, Asia, Africa, or North and South America. But if this is true, then a special case needs to be made for the legitimacy of the affirmation and deployment of African communalism. The Greeks worshipped mountains, found gods everywhere, and insisted that a being-out-of-community must be a god or a beast. They also held that the group is prior to the individual. Thus the idea of the individual that Senghor puts at the center of assembly society historically predated its emergence in the modern epoch, the epoch in which "money is king."

Aware of the commonalities shared by communalist societies in the West, Senghor did not fall into the error of essentializing Europe or Africa; he essentializes, if we must say so, agrarian, rural, community society and industrialized, urban-based assembly society. ${ }^{30}$ If this is true, different peoples will instantiate different society types, depending on the level of development of material and intellectual culture, or the sophistication and complexity of the division of labor that is attained by them. Societies sharing

Journal of French and Francophone Philosophy | Revue de la philosophie française et de langue française Vol XXIV, No 1 (2016) | http://www.jffp.org | DOI 10.5195/jffp.2016.759 
the same or similar material and intellectual culture tend to embody variations on the same institutional and ideational structures.

Senghor, too, like the other proponents of communalism identified above, mixes different theses of communalism. When he avers, "ours is a community society," he is advancing the ontological thesis; it is his description of what African societies are, what typifies them and, perchance, sets them apart from other societies. At least, he suggests that a key difference between African and European societies is that the former are marked by an organic unity among their members whereas the latter are marked by separation. If we could leave his advocacy at this level there would not be much to disagree with unless, of course, we have cause to argue that he has incorrectly described the phenomena in question. But Senghor thinks, as do others who defend communalism, that given their communalist pedigree, African societies are of the type that not only ought to be embraced but are indeed of a better order and more likely to redound to a better life for humans than their individualist rivals. In so doing, he slides into an embrace of the axiological thesis. Because he has not evinced any awareness of the different theses that he has lumped together, he ends up not providing solid arguments for his preferences. ${ }^{31}$

The contrast between Africa and Europe is badly drawn and likely to obfuscate rather than illuminate the nature of societies and the individuals that make them up. Have African societies always been "community societies" and European societies "collectivist" ones? What Senghor says later gives us reason to believe that he recognizes the historicity of the phenomena to be explained when he says that the character of West African societies has less to do with their being "African" but their being societies dominated by a certain mode of producing life and the wherewithal to sustain it. Senghor goes to great lengths to show that his defense of communalism has to do with the fact that, as of the time he was writing, "West African realities are those of underdeveloped countries-peasant countries here, cattle countries there-once feudalistic, but traditionally classless and with no wage-earning sector." ${ }^{32}$

This implies that communalism's pedigree is not traced to geography or history; rather, it is to be sourced in the modes of production of material life. If this is so, communalism is distributed across cultures and peoples who are otherwise distinct and different in their cultural productions would share communalism insofar as their modes of production are the same or very similar. And this, indeed, is what we find in the literature. Communalism is widely diffused across the globe from Europe to Asia and the Americas at specific historical conjunctures.

If this be granted, it means that were African countries to begin to produce life and maintain it differently, the "community" character that he is defending might also disappear or become attenuated with the extinction

Journal of French and Francophone Philosophy | Revue de la philosophie française et de langue française

Vol XXIV, No 1 (2016) | http://www.jffp.org | DOI 10.5195/jffp.2016.759 
of the mode of production that had earlier sustained it. As such, those who wish to recommend communalism may no longer deploy it as an ontological description. They may do so only as an axiological thesis either as ethics, as Wiredu does, or as political philosophy. But the justification can no longer be on account of its "Africanness". It must be on account of its desirability, primarily, and secondarily, its realizability. That desirability must extend to its universalizability. What this means is that, as a historicist, Senghor is not really defending communalism; he is recommending it as a caution to theorists not to formulate models that do not take account of the situation on the ground. He is counseling against the kind of dehistoricized accounts of communalism that have come to dominate the discussion since.

For Senghor, communalism, owing to the underdevelopment of material culture in our past societies, could be only one piece of a mixed template for social transformation at the present time and, for the future, the construction of the best life for humans, whoever or wherever they may be. He acknowledges the growing social differentiation in African societies and the fact that new templates $\backslash$ theories would have to accommodate these realities. He begins this with an acknowledgment that the presupposition of a classless society that is one of the fundaments of communalist thinking is no longer warranted. Needless to say, this has always been a problematic supposition. How one affirms of societies with monarchies and other assorted hierarchies that they were without severe social divisions has always escaped me. "Starting from this definition of the Negro-African community society, we can consider the special questions posed by the existence of distinct social groups in our West African society. This comprises three large sectors: (1) members of the liberal professions-lawyers, doctors, pharmacists, notaries, to whom we may add the merchants; (2) the wage earners-government officials, employees, and laborers; and (3) the peasants, shepherds, fishermen, and artisans." 33 Even if it was true that, when Senghor wrote the original piece, the groups "are less differentiated than in European society," I do not think that anyone would suggest that this continues to be the case. If we take seriously Senghor's position that we "consider the special questions posed by the existence of distinct social groups," any discussion of communalism now that does not take account of the increasing crystallization of class lines or the growing crystallization of social boundaries and indicate how contemporary versions of the idea will offset the complications fostered by changed circumstances cannot but be inadequate, to say the least.

Senghor's recognition of changed and changing circumstances might explain some of the other ambiguities in his formulations. His support for the fact that the "community society does not ignore the person even if it neglects the individual" is that "the member of the community society claims his autonomy to affirm himself as a being." Senghor has performed a verbal legerdemain here. It is the society that neglects the individual; this is

Journal of French and Francophone Philosophy | Revue de la philosophie française et de langue française Vol XXIV, No 1 (2016) | http://www.jffp.org | DOI 10.5195/jffp.2016.759 
the basic leitmotif of communalism-the priority of the group to the individual. The individual is only a person when he acts and presents himself as part of the group. At the point where he asserts himself as an individual, one that is independent of the group and whose being is understandable outside of the group, he becomes a nonperson. As a person, a being, every individual is no different from all the others in the group. To that extent, every person, as a being qua being, is infinitely substitutable for every other person.

The individual, on the other hand, and here is the problem, even in the most group-inflected setting, is marked by her individuality, something that sets her apart from, and renders her unique in the community of, other equally distinguished and differentiated individuals. This quality is much more than the simple acknowledgment by communalists that their theory recognizes individuality. As we just saw, it recognizes only individuality that does not deign to move itself away from a group inflection. When "community society" neglects this individual, makes her inferior to the community, bends her will to the collective preference, or denies her personhood, the being concerned has become a plaything, a tool of the community. At that point, it matters little what that individual "feels" or "thinks" respecting how and where "he can develop his potential, his originality." Simply put, he has not been given the choice; the decision has been made for him. He has not, we might say, been taken seriously. He has been rendered less than a person.

For us to believe that the individual is taken seriously there must be no prima facie decreeing that the individual must always yield to the group. What must happen instead is that the conflict must be acknowledged, not elided; and there must be a mechanism for adjudicating the conflict. The affirmation of the group interest must be based on good reasoning, not fiat. It is this kind of recognition of the legitimacy of individual difference that our communalists have not shown matters to them.

\section{VI}

I have argued that communalism is unpromising at the formal or theoretical level. At the material level, despite the popularity of communalism among African scholars and their repeated recommendation of it as the way out of Africa's contemporary existential funk, I would like to argue that, as a Yorùbá proverb says: "Aṣo kò bá Ọmoye mọ́; Omoye ti rin ihòhò dọjà." [The clothes came too late for Omoye; Omoye already marched naked into the town square.] There is no doubt that communalism enjoys wide appeal among African intellectuals. I suspect, though, that a lot of this appeal is traceable to the exigencies of embracing anything Western at the philosophical level and Africa's failure to interrogate the legacy of colonialist-inflected anthropology in our scholarship. The first makes

Journal of French and Francophone Philosophy | Revue de la philosophie française et de langue française

Vol XXIV, No 1 (2016) | http://www.jffp.org | DOI 10.5195/jffp.2016.759 
Africans recoil from considering, much less embracing, individualism, both as a principle of social ordering and a mode of social living because we mistakenly characterized it as a Western idea. The second inclines Africans to the metaphysics of difference manufactured by anthropology from not so noble building blocks in the nineteenth century. Due to these twin factors, African scholars are forever singing the praise of communal living, the virtues of the extended family, how Africans often and easily assume the burdens of being one another's brother's keeper, taking care of their old-no need for old people's home, thank you-and generally partaking of the gifts that "being-with-others" offers.

So deep is Africa's attachment to this orientation that we are not beyond using communalism as a metric for judging whether an individual can be considered a person, a version of ontological communalism. ${ }^{34}$ I sometimes wonder why Africans think that so-called Westerners are human at all given the near-synonymy that Africans affirm between communal living and being human. Yet, it takes but a cursory look at life as it is led across the continent to realize that there is a distinct disjuncture between the cherished ideological preferences of African scholars and the reality of everyday living for contemporary Africans. The reality is that individualism has been on a tear across the African continent for a long time now. The evidence is overwhelming.

Several years ago, I was in a conversation with a Nigerian anthropologist colleague who works mostly in what can broadly be described as urban anthropology. We were actually surprised by how unmindful we had been, up till that point, of the radically changed space within which we lived and which formed the physical location of that particular exchange: a unit in a 4-flat block built with individual entrances that made it possible for neighbors in the same yard not to run into one another at their respective entrances beyond a common yard shared by all. And this was in Ile-Ife, Nigeria. The spatial arrangement under reference is no longer atypical across the continent. So little does our architecture now owe to communalism and its associated values that our cities and towns, large and small, are devoid, for the most part, of common spaces for the unfolding of communal living, for example, public squares and parks.

The single-family residence is now the dominant, often preferred, definitely much sought after, context in which we lead our lives in both urban and rural areas. Of course, no thanks to the cleavage between our material reality and our warped apprehension of it, we frequently end up overwhelming the facilities and conveniences in our residences designed for modest use by nuclear families but now overstretched by extended family usage. The attainment of single-family residence is now the icon of success in our collective imagination; one that is aspired to by lettered and unlettered, rural and urban folks alike. And in some perverse way, when we elect to accommodate the so-called extended family, in some cases, we

Journal of French and Francophone Philosophy | Revue de la philosophie française et de langue française Vol XXIV, No 1 (2016) | http://www.jffp.org | DOI 10.5195/jffp.2016.759 
relegate them to the "Boys' Quarters" that our former colonial masters, in their vicious racism, reserved for their African servants who were not permitted to share the same space with them as a matter of sheer human interaction unmediated by the need for the servants' services!

Like individuals, African governments, too, are not noted for pursuing policies that are designed to enhance Africa's communalist values and enable Africans who so desire to realize their desires for communalist living with very low associated transaction costs. Incidentally, most of them are run by intellectuals and academics. By contrast, from mortgage deductions to deductions for costs of self-improvement, governments in countries dominated by individualism make bearable the costs of individualist living. ${ }^{35}$ Such preferences are based on the discourses of their intellectuals regarding conceptions of the best life for humans. I do not wish to nor can I stop African scholars from canvassing communalism as a model for social living and a principle of social ordering in Africa. My contention is that much of what is currently on offer represents inadequate justifications and less than sophisticated formulations at the theoretical level to serve as useful guides for practical life.

A defense of communalism in today's context that does not factor in the material circumstances of the contemporary situation across the continent strikes me as odd, possibly irrelevant. And I contend that our scholars argue for and defend communalism at the present time without taking seriously where Africa is. The ontological claim respecting how Africans are and how they organize themselves is undermined by the reality just described in the preceding section. Even if it might be said to reflect the Africa of a long gone era, it misapprehends, when it does not ignore or deny, the contemporary situation.

To insert the axiological thesis, say, in the area of politics, is to hanker after arrangements that are unlikely to be compatible with the growing tendency towards urbanization that is now predicted to have more than sixty percent of the African population living in cities and other urban agglomerations in the next ten years or so. It is even less plausible when it is ethics that is at issue. ${ }^{36}$ Needless to say, one can canvass any of these senses as philosophical exercises and I have no doubt that there will be a lot of light shed on many issues by so doing. What I object to is an attempt to win approbation by tugging at emotional strings as a kind of feel-good panacea to complex realities.

African scholars reserve the right to offer any prescription they fancy; I object because African communalism is completely sundered from the reality of the contemporary situation across the continent and in the global African world. I can see how the methodological thesis might be fruitful as an analytical device for making sense of African phenomena. Finally, it is time to jettison our fear of the West and stop trying to wish away our over

Journal of French and Francophone Philosophy | Revue de la philosophie française et de langue française

Vol XXIV, No 1 (2016) | http://www.jffp.org | DOI 10.5195/jffp.2016.759 
half a millennium engagement with things Western and our more than two hundred years' tangle with modernity. I would much rather have us take a hard look at modernity, come to terms with individualism, and come up with models that do not make a short work of it. ${ }^{37}$

Journal of French and Francophone Philosophy | Revue de la philosophie française et de langue française Vol XXIV, No 1 (2016) | http://www.jffp.org | DOI 10.5195/jffp.2016.759 
${ }^{1}$ For a more modest stance on this score, see Jare Oladosu, "J. S. Mill's Principle of Liberty and African Communalist Tradition," in Abdalla Bujra, ed., Political Culture, Governance and the State in Africa, (Nairobi: DPMF, 2011), pp. 203-234.

${ }^{2}$ For a different account of the theses of communalism, see Barry Hallen, A Short History of African Philosophy, $2^{\text {nd }}$ ed. (Bloomington: Indiana University Press, 2009), pp. 138-140.

${ }^{3}$ Examples include Ifeanyi S. Menkiti, "Person and Community in African Traditional Thought," in Richard Wright, ed., African Philosophy, $3^{\text {rd }}$ ed., (Lanham: University Press of America, 1984); "On the Normative Conception of a Person," in Kwasi Wiredu, ed., A Companion to African Philosophy (Malden, M.A.: Blackwell, 2004), pp. 324-331; John S. Mbiti, African Religions and Philosophy (London: Heinemann, 1970).

${ }^{4}$ See G.K. Osei, The African Philosophy of Life, $2^{\text {nd }}$ revised and enlarged ed. (London: The African Publication Society, 1971), chapters 3 and 4; E.A. Ruch and K.C. Anyanwu, African Philosophy: an Introduction to the Main Philosophical Trends in Contemporary Africa (Rome: Catholic Book Agency, 1981), pp. 369-383.

${ }^{5}$ See Akinsola Akiwowo, Ajobi and Ajogbe: Variations on the Theme of Sociation (Ile-Ife: University of Ife Press, 1983); "Contributions to the Sociology of Knowledge from an African Oral Poetry", in Martin Albrow and Elizabeth King, eds., Globalization, Knowledge and Society (London: SAGE, 1990); "Indigenous Sociologies: Extending the Scope of the Argument", International Sociology, vol. 14, no. 2 (June 1999), pp. 115-138.

${ }^{6}$ See Kwame Gyekye, Tradition and Modernity: Philosophical Reflections on the African Experience (Oxford: Oxford University Press, 1997), chapter 2; Tradition and Modernity; Kwasi Wiredu, Cultural Universals and Particulars: An African Perspective (Bloomington: Indiana University Press, 1996), chapters 6 and 13; Segun Gbadegesin, African Philosophy: Traditional Yoruba Philosophy and Contemporary African Realities (New York: Peter Lang, 1991), chapter 3. For those who have a preference for one-party rule, see Kenneth Kaunda; Julius Nyerere. There are others who argue the case for one-party rule but did not appeal to African antecedents, see, for example, Sekou Toure.

${ }^{7}$ Kwasi Wiredu does identify "communitarianism or individualism as an ethic." But it is one that is different from what we ordinarily identify with morality, for example, the Golden Rule. See "Social Philosophy in Postcolonial Africa: Some Preliminaries Concerning Communalism and Communitarianism," in South African Journal of Philosophy, vol. 27, no. 4 (2008), p. 334 [Hereafter cited as Wiredu, "Social Philosophy in Postcolonial Africa."].

${ }^{8}$ Polycarp Ikuenobe, Philosophical Perspectives on Communalism and Morality in African Traditions (Lanham: Lexington Books, 206), chapter 5.

${ }^{9}$ For a similar view, see Jare Oladosu, "J. S. Mill's Principle of Liberty and African Communalist Tradition," in Abdalla Bujra, ed., Political Culture, Governance and the State in Africa, (Nairobi: DPMF, 2011), pp. 214215. Wiredu affirms the opposite. See "Social Philosophy in Postcolonial Africa.", p. 333.

${ }^{10}$ (Lanham: Lexington Books, 2006).

${ }^{11}$ Ikuenobe, p. 16.

12 Olufemi Taiwo, "Legal Positivism and the African Legal Tradition: a Reply," International Philosophical Quarterly, XXV, 2 (1985), pp. 197-200.

${ }^{13}$ Ikuenobe, p. 33. 
${ }^{14}$ Ikuenobe, p. 44.

${ }^{15}$ Ikuenobe, p. 45.

${ }^{16}$ Ikuenobe, p. 5 .

${ }^{17}$ I will not detain the reader with the cruder formulations of African communalism in the literature. For example, see Joseph M. Nyasani, "The Ontological Significance of 'I' and 'We' in African Philosophy”, in H. Kimmerle, ed., We and Body: First Joint Symposium of Philosophers from Africa and the West (Atlantic Highlands: Gruner, 1989).

${ }^{18}$ Leopold Sedar Senghor, On African Socialism, trans. and intro., Mercer Cook (London: Pall Mall Press, 1964).

${ }^{19}$ Might it also be ontological, in a somewhat muted sense? That is, Senghor is describing the nature of something, not necessarily of Africans, but social forms that have emerged from the history of social evolution in Africa.

${ }^{20}$ Senghor, p. 93. Again, we find an attention to historicity that is not to be found in most discussion of communalism. It is as if African history and life do not deserve any periodization more sophisticated than the ever popular but theoretically vacuous precolonial, colonial and post-colonial periods. For a similar move to combine the different legacies at work in Africa in the constitution of a philosophical model for rebuilding the fortunes of the continent and its peoples, see Kwame Nkrumah, Consciencism (London: Panaf Books, 1970). Although I do not do so here, one can make a plausible case for denying that Senghor subscribed to communalism. As I point out later in this discussion, he took a historicist view of human nature and he was insistent that we mind historical changes and incorporate them into our analyses and explanatory models. He did this in his own writings. This is a point of difference between him and Julius Nyerere. There is no commitment in Senghor to the kind of autarky on which Nyerere sought to build his Ujamaa model. On the contrary Senghor describes how "our present society is in fact an original one". The originality had nothing to do with original roots in Africa. Rather it was original in the sense of it being a new emergence from the combination of "African and European contributions". We need to read Senghor more carefully. This idea of originality as hybridity is a core element in Senghor's philosophy, generally. See Cheikh Thiam, Return to the Kingdom of Childhood: Re-envisioning the Legacy and Philosophical Relevance of Negritude (Columbus: Ohio State University Press, 2014), especially chapter 3.

${ }^{21}$ Senghor, p. 77.

${ }^{22}$ Senghor, pp. 93-94.

${ }^{23}$ This is almost standard in the literature on communalism.

${ }^{24}$ This is an abbreviated characterization. A fuller exploration will look at the philosophical suppositions that each standpoint is built upon.

${ }^{25}$ Wiredu, "Social Philosophy in Postcolonial Africa: Some Preliminaries Concerning Communalism and Communitarianism," p. 334.

${ }^{26}$ Senghor, p. 94.

${ }^{27}$ See John S. Mbiti, African Religions and Philosophy (London: Heinemann, 1970); Ifeanyi S. Menkiti, "On the Normative Conception of a Person," Kwasi Wiredu, ed., A Companion to African Philosophy (Malden, MA: Blackwell, 2004), pp. 324-331).

${ }^{28}$ But it is not one to be dismissed lightly. Similar views of the individual are to be met with in Plato, The Republic and in Socrates's justification for submitting to the punishment of the court in The Apology. 
${ }^{29}$ There is a consistency to Senghor's affirmations, though. At the end of the quoted passage, he indicates that persons are beings alongside other beings such as "God, animal, tree or pebble". This affirmation raises a whole new set of questions. I do not suppose that pebbles, trees, etc., "think, feel" in terms of "developing their potential, etc." in communion with others. This capacity for thinking or feeling injects a quirky moment into the framework that threatens the play of heterodoxy that is not easily accommodated by professions of near transparency in the person-community relation.

${ }^{30}$ This may be Senghor's nod to the Marxism he admired but criticized for ignoring the spirit.

${ }^{31}$ But all it takes is to look at the whole of Senghor's political writings to see that this interest in communalism did not define his political philosophy. He did eventually settle for liberal parliamentary democracy with a strong emphasis on protecting the individual and African community society.

${ }^{32}$ Senghor, p. 77.

${ }^{33}$ Senghor, p. 94 . My emphasis.

${ }^{34}$ See Ifeanyi Menkiti, "Person and Community in African Traditional Thought", Richard Wright, ed., African Philosophy: an Introduction, $3^{\text {rd }}$ ed., (Lanham: University Press of America, 1984); John S. Mbiti, African Religions and Philosophy (New York: Doubleday\Anchor Books, 1970); Polycarp Ikuenobe, Philosophical Perspectives on Communalism and Morality in African Traditions; Nyasani, "The Ontological Significance of 'I' and 'We' in African Philosophy".

${ }^{35}$ For how this is tied to a commitment to individualism see, Taiwo, Africa Must Be Modern: A Manifesto, chapter 2.

${ }^{36}$ Wiredu does try to meet this challenge by advocating what he calls "consensual politics" based on his communalist reading of "African traditions". See Kwasi Wiredu, "Democracy and Consensus: A Plea for a Non-Party Polity," in Cultural Universals and Particulars: An African Perspective (Bloomington: Indiana University Press, 1996).

${ }^{37}$ This paper started its life as a presentation to the "Invited Papers" Session at the 105th Annual Meeting of the American Philosophical Association, Eastern Division, Hilton Hotel, Philadelphia, PA, December 27-30, 2008. An updated version was given at the XVIIth Annual Conference of the International Society for African Philosophy and Studies (ISAPS), at the University of Ghana, Legon, Accra, Ghana, March 17-19, 2010. Work on later versions of the piece was supported by a 2011 Summer Faculty Research Fellowship awarded to me by the College of Arts and Sciences, Seattle University. The paper has benefitted from the insights and challenges of those who honored me with their presence and contributions at the earlier presentations in Philadelphia and Accra. I particularly want to thank Barry Hallen for extensive comments on an earlier draft that have considerably improved the text. Its most recent iteration was presented to the Workshop on "African Thinking and/at Its Limits" at the Africana Studies and Research Center, Cornell University, Ithaca, NY, June 25-26, 2015. I am grateful to the participants at the workshop and in particular to Professor Grant Farred for his many helpful suggestions for this current version.

Journal of French and Francophone Philosophy | Revue de la philosophie française et de langue française Vol XXIV, No 1 (2016) | http://www.jffp.org | DOI 10.5195/jffp.2016.759 